\title{
Conflict of Legal Norms Regarding Regulation of Creditors of Encumbrance Rights Holders in the Debtor's Bankruptcy in Indonesia
}

\author{
Siti Malikhatun Badriyah ${ }^{1}$, R. Suharto ${ }^{2}$, Siti Mahmudah ${ }^{3}$, Bambang Eko Turisno ${ }^{4}$, \\ Muhammad Shafiyuddin Wafi ${ }^{5}$ \\ \{ sitimalikhatun@live.undip.ac.id ${ }^{1}$,r.suhartoo@gmail.com², sitimahmudah.fhundip@gmail.com³ \\ eko.turisno@live.undip.ac.id ${ }^{4}$, m.wafi72@gmail.com $\left.{ }^{5}\right\}$ \\ 1,2,3,4,5 Faculty of Law, Diponegoro University Semarang, Indonesia
}

\begin{abstract}
Encumbrance Rights is one of the material guarantees. The main function of guarantees is to provide creditors with confidence that the debtor will carry out the agreement. The existence of collateral gives a preferred position to the creditors of encumbrance rights holders. In addition, Encumbrance Rights Holders also hold the position as separatist creditors. This is confirmed in the Encumbrance Rights Act and the Bankruptcy Act. On the other hand, the Bankruptcy Law also regulates the existence of a waiting period which undermines the rights of separatist creditors. The study aims to create a model to resolve conflicting legal norms to provide legal protection to creditors of encumbrance rights holders in debtor bankruptcy. The research uses socio legal research method. The facts show that there is a conflict of legal norms regarding the arrangement of Encumbrance Rights Holder between the Encumbrance Right Guarantee Act and the Bankruptcy Act, resulting in a dispute in the implementation of the encubrance rights in the case of a bankrupt debtor. This results in the absence of legal certainty and lack of legal protection for creditors of Encumbrance Rights Holder.
\end{abstract}

Keywords: Conflict, Legal Norms, Encumbrance Rights, Separatist Creditors, Bankruptcy

\section{Introduction}

Legal norms contain legal principles and regulations.[1] A law must contain three basic values, namely, justice, expediency and legal certainty. [2] One of the legal norms in business activities is the regulation of collateral.

A company's need for capital can be fulfilled internally and externally. In fulfilling this need for capital from external sources, financial institutions face a high risk, hence it requires collaterals. Guarantees are used to provide security against default risk in business practices. [3] For the security of creditors from the risk of default on creditor receivables, it is important to control moral hazards in financial institutions and ensure financial sustainability from public intervention. [4] Regulation on mortgages is needed in credit management to anticipate the risks that financial institutions have to face. [5]

The principle of guarantee in various countries including Indonesia, for immovable objects uses mortgages. Mortgages are contracts to convince creditors to pay off debtors' debts. [6] Mortgages become one of the considerations for creditors in assessing the debtor's eligibility. [7] After its entry into force, the Encumbrance Act sets forth that if a land becomes 
a collateral object, the Encumbrance Rights shall then be used. A land is an immovable object. Other countries, such as China, [8] Sweden, [9] the Netherlands, [10] Egypt, [11] United Kingdom, Australia, Japan, [5], United Kingdom [5], use mortgage institutions for when immovable property is used as a guarantee.

As collateral, the Encumbrance Right is characterized by its absolute right, giving a preferential position, i.e. the position to be preferred in the repayment of its receivables over other creditors. In addition, creditors also hold a separatist position, i.e. creditors who are not affected by debtor bankruptcy (Article 21 of the Underwriting Rights Law in conjunction with Article 55 paragraph (1) of the Bankruptcy Act).

Article 1 number 1 of the Bankruptcy Law states that "Bankruptcy is a general confiscation of all assets of bankrupt debtors whose management and settlement is carried out by a curator under the supervision of a supervisory judge". Bankruptcy has significant consequences for different groups of people as well as important problems for companies. Therefore, it is necessary to predict and anticipate the occurrence of bankruptcy and the risk of non-payment of creditors' account receivables.[12] Bankruptcy prediction is useful, among other things, to provide protection for business actors, both financial institutions and shareholders, to realize investment choices. [13]. Bankruptcy prediction also serves for early anticipation of the management of a company's financial position. [14] One effort to predict and anticipate bankruptcy is the imposition of material guarantees, one of which is mortgage.

In case of debtor bankruptcy, the creditor of the encumbrance right holder can directly execute the collateral object. This is because the collateral object is separate from other assets. Encumbrance Right objects are not included in bankrupt assets. The norms regarding Encumbrance Rights holders in the case of bankrupt debtors are set forth in the Encumbrance Rights Act and the Bankruptcy Act. The facts show that in Indonesia there are conflicting norms regarding the arrangement of creditors who are also holding the encumbrance rights in the case of bankrupt debtors.

"Arner et al.'s research shows that China, Indonesia, the Philippines, and Vietnam adopt the U.S. approach by which secured creditors are subject to an automatic stay in both liquidations and reorganizations. In contrast, in South Korea, Singapore, and Thailand, secured creditors are subject to a moratorium in reorganizations, but not in liquidations or compositions. Lastly, secured creditors of companies in Hong Kong, Malaysia, and Taiwan may act unilaterally outside both bankruptcy and reorganization. [15]

The conflict of norms in the regulation of creditors holding Encumbrance Rights in debtors bankruptcy in Indonesia results in the lack of legal certainty and legal protection for creditors. This often results in conflicts that result in disputes in court. To make things worse, even in court the judges have different interpretations of similar cases. The problem of this research is, therefore, how is the settlement model that can reduce conflicts of law norms regarding the regulation of Creditors of Encumbrance Rights holder in case of debtor bankruptcy? The research uses socio legal research method that integrates state law (positive law) and living law.

\section{Discussion}

\subsection{Conflict of Legal Norms in the Arrangement of Creditors of Encumbrance Rights Holder in case of Debtor Bankruptcy}

Creditors of Encumbrance Rights Holders have a strong position because they hold the position as preferred creditors and separatist creditors. Preferred creditors are creditors who 
have the right to receive the payment of receivables and to be preferred over other creditors. The encumbrance right holder has the right to execute without having to file a lawsuit in the case of defaulting debtors.

Separatist creditors are those creditors who are not affected by the debtor's policy. Article 21 of the Encumbrance Right Act states that "If the Encumbrance Right Provider is declared bankrupt, the Encumbrance Right Holder is still authorized to exercise all the rights they obtain according to the provisions of the Law".

Based on Articles 55 and 244 Paragraph 1 of the Bankruptcy Act, separatist creditors, in principle, are placed outside the debtor's bankruptcy, because it has the right of collateral. Therefore, the Creditors of the Encumbrance Right Holder have the right to self-execute collateral for repayment of their receivables.

Article 56 Paragraph (1) of the Bankruptcy Act, however, shows different arrangements with the provisions of Article 55 above. Article 56 Paragraph (1) provides that the right to execute a creditor is suspended for a maximum period of 90 (ninety) days from the date the bankruptcy statement is pronounced. Thus inconsistencies occur in the regulation of Bankruptcy. In that case there has been a conflict of legal norms in the regulation of Creditors of Encumbrance Right Holders in the case of debtor's bankruptcy.

The provisions of Article 56 are also not consistent with Article 21 of the Encumbrance Rights Act, which stipulates that the creditor holding the Encumbrance Right has the authority to exercise all the rights that they have obtained in accordance with the Encumbrance Right Act.

Furthermore, in Article 59 of the Bankruptcy Act, it can be seen that after the debtor is declared in insolvency, then the creditor holding the Encumbrance Rights must be able to sell the object of the Encumbrance Right in the manner determined by Article 20 of the Encumbrance Right Act j.o. Article 60 of the Bankruptcy Act. After the debtor is declared in insolvency, the object of the Encumbrance Rights is the property outside of bankruptcy. On the other hand the execution rights of the creditor holding the Encumbrance Right to the Encumbrance Rights object are limited to 2 months. After this period has passed, it will be taken over by the curator. Article 59 of the Bankruptcy Act has limited the authority of creditors holding the Encumbrane Rights to exercise their rights under Article 20 paragraph (1) of the Encumbrance Rights Act.

The limitations set forth in the Bankruptcy Act result in a conflict of norms in the regulation of the Creditors' Rights holders in debtor bankruptcy. As a result there is no legal certainty, because it gives rise to different interpretations. The limitation regulation by the Bankruptcy Law results in the lack of legal protection for the Creditors' account receivables.

According to Sergio Nasarre-Aznar, [16] the implementation of Act and court rulings is very influential on legal certainty. Different decisions carry great risks. This causes uncertainty and leads to externalities including lack of international trust in banks in the country concerned. This can lead to a wider liquidity crisis, (M.Teresa Sánchez-Martínez and Dolores Moreno-Herrero 2016) resulting in greater public spending on their sustainability. Legal frameworks with different levels of national law and legal uncertainty about the rules applied can weigh on the value of mortgage collateral and financial market stability. Moreover, this impact can have a continued impact on the provision of credit institutions and the flow of credit to the economy and the functioning of financial institutions.

Therefore, it should be returned to the main objective of collateral, i.e. to give creditors the confidence that their receivables will return to them. Thus, their rights should receive legal protection in the event that there is interference with these rights. In such a case if a case is brought before a court, the judge has a central role in resolving the matter. Judges as law 
enforcers in court play a central role, especially in the case that there are no legal regulations or there are legal regulations, yet they are not too clear. Hence, the role of judges is very important to give decisions that provide justice, usefulness and legal certainty. For this reason, the legal discovery by the judge as stated by Sudikno Mertokusumo as mentioned above Zulfa Aulia [18] is highly recommended.

Based on the facts described above, the following suggestions should be done immediately.

Firstly, the legislators should immediately synchronize the laws and regulations by ammending the laws and regulations. In addition, it is very necessary to have laws and regulations regarding guarantees in an integrated manner, so that there would be no conflicting legal norms between laws and regulations regarding guarantees. The state and law are instruments of humanity and justice. Thus the state and the law must link it with humanity and justice.

Secondly, as long as there are no new laws and regulations, the judges in courts in charge of resolving the disputes shall make legal discoveries based on the principle of a special guarantee institution in the form of material guarantees to better provide justice for the community in general and the parties in particular. In adjudicating and making decisions, judges must make legal discoveries so that their decisions give birth to actual and beneficial justice for the community. In law enforcement, the focus must be on the integrity and professionalism of law enforcement officials, especially in the Judiciary, to administer justice in order to uphold law and justice based on Pancasila and the 1945 Constitution of the Republic of Indonesia.

Thirdly, the function of state supervision of the implementation of Encumbrance Rights must be further optimized. It is important to oversee the financial sustainability of companies to anticipate the possibility of bankruptcy. Financial management of companies with a sustainability model is needed to have the stakeholders playing an active role. To avoid the consequences of corporate financial instability that can impact the emergence of bankruptcy, collaborative efforts can be made between companies.

Fourthly, business actors both financial and non-financial institutions should pay a greater attention on sustainable financial management. This is very necessary to prevent financial instability, including management of the company's debt and receivables.

Fifthly, the government should form a special insurance for mortgages and mortgage rights. It is very necessary to provide more certainty and legal protection to the parties, both business actors and the general public. Public confidence, whether local, regional or international, is strongly influenced by various factors, one of which is the creditors' credit security. Mortgages and mortgage rights are one way that goes hand in hand with the principles of benefits, justice and legal certainty.

\section{Conclusion}

Article 1132 of the Civil Code and Article 1 Number 1 of the Encumbrance Rights Act in conjunction with Article 21 of the UUHT and Article 55 Paragraph (1) of the Bankruptcy Act provides authority to separatist creditors to exercise their rights in the event of debtor bankruptcy. This is in accordance with the principle of guarantee law which sets forth that the main function of collateral is to provide creditors with confidence in repaying the debtors' debts. In this case the creditor's position is as a preferred creditor and at the same time as a separatist creditor. Therefore, in case the debtor is declared in bankruptcy, the creditor can execute the object of mortgage as if the debtor bankruptcy does not occur. However, Articles 
56 and 59 of the Bankruptcy Act provide limits on the creditor's rights, thus in this case there is a conflict of legal norms. Conflicts of legal norms in the regulation of the Encumbrance Rights Holders in debtor bankruptcy lead to different interpretations in practice, resulting in legal uncertainty and lack of legal protection for creditors. Therefore, it is necessary to take various steps to overcome conflicts of legal norms in regulating creditor rights holders in the case of debtor bankruptcy. This is so that the principles of holding guarantees in the business world will be the right means to support the stability of the company and create confidence in business people as well as in the Indonesian and international community.

Acknowledgment. We would like to extend our gratitude to the Rector of Diponegoro University, Dean of the Faculty of Law of Diponegoro University, LPPM Diponegoro University, and the Committee and participants of the of the ICIDS organized by Sekolah Tinggi Ilmu Ekonomi dan Bisnis Islam Lampung on 10th-Sept,2019.

\section{Reference}

[1] E. A. Posner, Contract Law \& Theory (Aspen Treatise Series). Aspen Publishers, 2011.

[2] S. M. Badriyah, Aspek Hukum Anjak Piutang. Semarang: Madina, 2015.

[3] N. Mugarura, "Different types of guarantee schemes and their usage in safeguarding against default risks in international commercial practice," Int. J. Law Manag., vol. 58, no. 5, pp. 507-522, 2016.

[4] L. Gai, F. Ielasi, and M. Rossolini, "SMEs, public credit guarantees and mutual guarantee institutions," J. Small Bus. Enterp. Dev., vol. 23, no. 4, pp. 1208-1228, 2016.

[5] Y. Moriizumi et al., "Household mortgage demand: a study of the UK, Australia and Japan," Int. J. Hous. Mark. Anal., 2018.

[6] B. Bidabad, "Mortgage Securitization System (MSS) (a complementary system of Rastin Banking)," Int. J. Law Manag., vol. 59, no. 6, pp. 778-783, 2017.

[7] E. M. Ozhegov, "Heterogeneous preferences of Russian residential mortgage borrowers," J. Eur. Real Estate Res., vol. 10, no. 1, pp. 35-56, 2017.

[8] C. Gan, Z. li, W. Wang, and B. Kao, "Credit scoring in mortgage lending: Evidence from China,” Int. J. Hous. Mark. Anal., vol. 5, no. 4, pp. 334-350, 2012.

[9] M. Hullgren, "Mortgage decisions in Swedish housing co-operatives," Int. J. Hous. Mark. Anal., vol. 10, no. 4, pp. 572-584, 2017.

[10] M. K. Francke and F. P. W. Schilder, "Losses on Dutch residential mortgage insurances," J. Eur. Real Estate Res., vol. 7, no. 3, pp. 307-326, 2014.

[11] A. A. G. Hassanein and M. M. G. El-Barkouky, "The Egyptian mortgage practice," Int. J. Manag. Proj. Bus., vol. 1, no. 2, pp. 260-278, 2008.

[12] S. Ramakrishnana, M. Mirzaeib, and M. Naveedc, "Corporate Bankruptcy Prediction: A Case of Emerging Economies," Int. J. Sci. Basic Appl. Res., vol. 19, no. 1, p. 177187., 2015.

[13] X. Brédart, "Bankruptcy Prediction Model: The Case of the United States," Int. J. Econ. Financ., vol. 6, no. 3, pp. 1-7, 2014.

[14] M. S. Roomi, W. Ahmad, M. Ramzan, and M. Zia-ur-Rehman, "Bankruptcy Prediction for Non-Financial Firms of Pakistan," Int. J. Account. Financ. Report., vol. 5, no. 2, p. 26, 2015.

[15] D. W. Arner, C. D. Booth, P. Lejot, and B. F. C. Hsu, "Property rights, collateral, creditor rights, and insolvency in East Asia," Commer. Law East Asia, pp. 25-70, 2017. 
[16] S. Nasarre-Aznar, “Robinhoodian' courts' decisions on mortgage law in Spain,” Int. J. Law Built Environ., vol. 7, no. 2, pp. 127-147, 2015.

[17] M.TeresaSánchez-Martínez and J.-C. DoloresMoreno-Herrero, "No Title," Int. JournalofHousing Mark. Anal., vol. 9, no. 3, 2016.

[18] M. Z. Aulia, "Hukum Progresif dari Satjipto Rahardjo: Riwayat, Urgensi, dan Relevansi," Undang J. Huk., vol. 1, no. 1, pp. 59-185. 